\title{
Enoxaparin versus Unfractionated Heparin with Fibrinolysis for ST-Elevation Myocardial Infarction
}

\author{
Elliott M. Antman, M.D., David A. Morrow, M.D., M.P.H., Carolyn H. McCabe, B.S., \\ Sabina A. Murphy, M.P.H., Mikhail Ruda, M.D., Zygmunt Sadowski, M.D., \\ Andrzej Budaj, M.D., Jose L. López-Sendón, M.D., Sema Guneri, M.D., \\ Frank Jiang, M.D., Ph.D., Harvey D. White, D.Sc., Keith A.A. Fox, M.B., Ch.B., \\ and Eugene Braunwald, M.D., for the ExTRACT-TIMI 25 Investigators*
}

\section{ABSTRACT}

\section{BACKGROUND}

Unfractionated heparin is often used as adjunctive therapy with fibrinolysis in patients with ST-elevation myocardial infarction. We compared a low-molecular-weight heparin, enoxaparin, with unfractionated heparin for this purpose.

\section{METHODS}

We randomly assigned 20,506 patients with ST-elevation myocardial infarction who were scheduled to undergo fibrinolysis to receive enoxaparin throughout the index hospitalization or weight-based unfractionated heparin for at least 48 hours. The primary efficacy end point was death or nonfatal recurrent myocardial infarction through 30 days.

\section{RESULTS}

The primary end point occurred in 12.0 percent of patients in the unfractionated heparin group and 9.9 percent of those in the enoxaparin group (17 percent reduction in relative risk, $\mathrm{P}<0.001)$. Nonfatal reinfarction occurred in 4.5 percent of the patients receiving unfractionated heparin and 3.0 percent of those receiving enoxaparin (33 percent reduction in relative risk, $\mathrm{P}<0.001$ ); 7.5 percent of patients given unfractionated heparin died, as did 6.9 percent of those given enoxaparin $(\mathrm{P}=0.11)$. The composite of death, nonfatal reinfarction, or urgent revascularization occurred in 14.5 percent of patients given unfractionated heparin and 11.7 percent of those given enoxaparin $(\mathrm{P}<0.001)$; major bleeding occurred in 1.4 percent and 2.1 percent, respectively $(\mathrm{P}<0.001)$. The composite of death, nonfatal reinfarction, or nonfatal intracranial hemorrhage (a measure of net clinical benefit) occurred in 12.2 percent of patients given unfractionated heparin and 10.1 percent of those given enoxaparin $(\mathrm{P}<0.001)$.

\section{CONCLUSIONS}

In patients receiving fibrinolysis for ST-elevation myocardial infarction, treatment with enoxaparin throughout the index hospitalization is superior to treatment with unfractionated heparin for 48 hours but is associated with an increase in major bleeding episodes. These findings should be interpreted in the context of net clinical benefit. (ClinicalTrials.gov number, NCT00077792.)
From the Thrombolysis in Myocardial Infarction (TIMI) Study Group, Cardiovascular Division, Department of Medicine, Brigham and Women's Hospital and Harvard Medical School, Boston (E.M.A., D.A.M., C.H.M., S.A.M., E.B.); the Department of Emergency Cardiology, Cardiology Research Center, Moscow (M.R.); the National Institute of Cardiology (Z.S.) and the Postgraduate Medical School, Department of Cardiology, Grochowski Hospital (A.B.) - both in Warsaw, Poland; Hospital Universitario La Paz, Madrid (J.L.L.-S.); Dokuz Eylul Universitesi, Izmir, Turkey (S.G.); International Clinical Development, Sanofi-Aventis, Bridgewater, N.J. (F.J.); Green Lane Cardiovascular Service, Auckland City Hospital, Auckland, New Zealand (H.D.W.); and the University of Edinburgh, Cardiovascular Research, Edinburgh (K.A.A.F.). Address reprint requests to Dr. Antman at the TIMI Study Group, Cardiovascular Division, Brigham and Women's Hospital, 75 Francis St., Boston, MA 02115, or at eantman@rics. bwh.harvard.edu.

\section{*The participants in the Enoxaparin and Thrombolysis Reperfusion for Acute Myo- cardial Infarction Treatment (ExTRACT)- Thrombolysis in Myocardial Infarction (TIMI) 25 Study are listed in the Ap- pendix.}

This article was published at www.nejm.org on March 14, 2006.

N Engl J Med 2006;354:1477-88 Copyright $\odot 2006$ Massachusetts Medical Society. 
F IBRINOLYSIS IS THE MOST COMMON method of reperfusion used worldwide for patients with ST-elevation myocardial infarction. In addition to advocating that a fibrinolytic agent be combined with aspirin, contemporary guidelines recommend the routine administration of unfractionated heparin. ${ }^{1,2}$ Despite receiving a regimen of a fibrinolytic agent, aspirin, and unfractionated heparin, a substantial number of patients die or have another nonfatal myocardial infarction within one month after treatment. ${ }^{3-9}$ Prolonged intravenous infusions of unfractionated heparin have not been shown to prevent reocclusion after angiographically proven successful fibrinolysis, leading to the current recommendation to limit the duration of infusion to 48 hours. ${ }^{1,2}$ The use of unfractionated heparin requires frequent monitoring to adjust the infusion rate to maintain a therapeutic range of anticoagulation. ${ }^{10}$

The low-molecular-weight heparins are potential replacements for unfractionated heparin. ${ }^{11,12}$ As compared with unfractionated heparin, enoxaparin (Lovenox, Sanofi-Aventis) provides both a reliable level of anticoagulation without the need for therapeutic monitoring and relatively greater proximal inhibition of the coagulation cascade because it results in a ratio of anti-factor Xa to anti-factor IIa activity of 3.8:1.10 The Enoxaparin and Thrombolysis Reperfusion for Acute Myocardial Infarction Treatment (ExTRACT)-Thrombolysis in Myocardial Infarction (TIMI) 25 study was designed to compare enoxaparin and unfractionated heparin as adjunctive therapy for fibrinolysis in ST-elevation myocardial infarction. ${ }^{11}$ Because of the advantage offered by the ability to administer enoxaparin subcutaneously, we tested a strategy in which enoxaparin was administered for the duration of the index hospitalization, to decrease the risk of reocclusion of the infarct artery. Since enoxaparin reportedly increases the risk of bleeding in elderly patients, ${ }^{13}$ we devised a specific dosing regimen for patients 75 years of age or older and reduced the dose in patients of any age who had a clinically significant impairment in renal function. ${ }^{11}$

\section{METHODS}

\section{PATIENT POPULATION}

Between October 24, 2002, and October 1, 2005 , 20,506 patients underwent randomization at 674 sites in 48 countries (see the Appendix). Eligible patients were at least 18 years of age, had at least
20 minutes of ischemic symptoms while at rest within 6 hours before randomization, had ST-segment elevation of at least $0.1 \mathrm{mV}$ in two limb leads or of $0.2 \mathrm{mV}$ in at least two contiguous precordial leads or had left bundle-branch block, and were scheduled to undergo fibrinolysis with streptokinase, tenecteplase, alteplase, or reteplase. ${ }^{11}$ Patients were ineligible if they had any of the following major exclusion criteria: cardiogenic shock, pericarditis, symptoms of aortic dissection, contraindications to fibrinolysis, receipt of a low-molecular-weight heparin within the prior eight hours, known renal insufficiency (defined by a serum creatinine level of greater than $220 \mu \mathrm{mol}$ per liter [2.5 $\mathrm{mg}$ per deciliter] for men and greater than $175 \mu \mathrm{mol}$ per liter [2.0 mg per deciliter] for women), or a life expectancy of less than 12 months. ${ }^{11}$

The protocol was approved by the local institutional review board at participating centers. Written informed consent was obtained from all patients in the intention-to-treat and safety populations, except for six, who provided oral informed consent.

\section{STUDY PROTOCOL}

Patients were to receive, at the treating physician's discretion, streptokinase, tenecteplase, alteplase, or reteplase according to the manufacturers' instructions for the treatment of ST-elevation myocardial infarction. All patients were to receive 150 to $325 \mathrm{mg}$ of aspirin in a nonenteric formulation orally or $500 \mathrm{mg}$ intravenously unless they had received at least $325 \mathrm{mg}$ of aspirin within the prior 24 hours. After the first 24 hours, maintenance therapy with 75 to $325 \mathrm{mg}$ of aspirin once daily was to be administered orally for at least 30 days. Alternative antiplatelet agents such as clopidogrel could be used in patients with an allergy to aspirin, or they could be added to aspirin at the investigator's discretion, as part of the patient's treatment regimen.

Patients were randomly assigned in a 1:1 ratio to receive enoxaparin or unfractionated heparin with the use of a central, computerized system, according to the type of fibrinolytic agent. Study medication was to be administered in a doubleblind fashion with the use of a double-dummy design between 15 minutes before and 30 minutes after the initiation of fibrinolytic therapy and was to occur within 30 minutes after randomization.

Unfractionated heparin (or matching placebo) was to be administered beginning with an intravenous bolus of $60 \mathrm{U}$ per kilogram of body weight 
(maximum, $4000 \mathrm{U}$ ). The intravenous bolus was to be omitted for patients who received open-label unfractionated heparin (at least $4000 \mathrm{U}$ ) within three hours before randomization. Within $15 \mathrm{~min}$ utes after the intravenous bolus, an infusion of $12 \mathrm{U}$ per kilogram per hour (initial maximum, $1000 \mathrm{U}$ per hour) was begun. All monitoring of anticoagulation to adjust the dose of unfractionated heparin to maintain an activated partialthromboplastin time of 1.5 to 2.0 times the control value was performed in a blinded fashion by personnel caring for the patient or in an unblinded fashion by a designated medical professional not involved in the patient's care. ${ }^{11}$ The intravenous infusion was to be given for at least 48 hours but could be continued for a longer period at the treating physician's discretion.

The enoxaparin dosing strategy was adjusted according to the patient's age and renal function. For patients younger than 75 years of age, enoxaparin (or matching placebo) was to be given as a fixed, 30-mg intravenous bolus followed $15 \mathrm{~min}$ utes later by a subcutaneous injection of $1.0 \mathrm{mg}$ per kilogram, with injections administered every 12 hours. For patients at least 75 years of age, the intravenous bolus was eliminated and the subcutaneous dose was reduced to $0.75 \mathrm{mg}$ per kilogram every 12 hours. For the first two subcutaneous injections, a maximum of $100 \mathrm{mg}$ (for patients less than 75 years old) or $75 \mathrm{mg}$ (for those at least 75 years old) was to be administered. To reduce the risk of bleeding, the intravenous bolus was to be omitted for patients who received open-label unfractionated heparin (at least $4000 \mathrm{U}$ ) within three hours before randomization. For patients with an estimated creatinine clearance of less than $30 \mathrm{ml}$ per minute, the dose was to be modified to $1.0 \mathrm{mg}$ per kilogram every 24 hours. ${ }^{11}$ The double-blind subcutaneous injections of enoxaparin or matching placebo were to continue until hospital discharge or for a maximum of eight days (whichever came first).

Although percutaneous coronary interventions could be performed at any time as rescue therapy for failed fibrinolysis or urgently, in response to an episode of recurrent myocardial ischemia or infarction, the protocol recommended the deferral of elective procedures for at least 48 hours after randomization. Patients undergoing percutaneous coronary interventions were to receive antithrombotic support with masked study drug, which could be discontinued after uncomplicated procedures at the discretion of the treating physi- cian. ${ }^{11}$ Patients were monitored for clinical end points and adverse events during the index hospitalization and through day 30 (ascertained, day 31 to 38 ) in person or by telephone.

\section{END POINTS}

The primary efficacy end point was the composite of death from any cause or nonfatal recurrent myocardial infarction in the first 30 days after randomization. The main secondary end point was the composite of death from any cause, nonfatal reinfarction, or recurrent myocardial ischemia leading to urgent revascularization in the first 30 days. An additional secondary end point (net clinical benefit) was the composite of death from any cause, nonfatal reinfarction, or nonfatal disabling stroke. We included two other prespecified net-clinicalbenefit end points: first, death, nonfatal recurrent myocardial infarction, or a nonfatal episode of major bleeding; and second, death, nonfatal myocardial infarction, or nonfatal intracranial hemorrhage. Bleeding was classified according to the TIMI criteria. ${ }^{11}$ All ischemic and clinically significant bleeding events were adjudicated in a blinded fashion by an independent clinical-events committee using prespecified definitions. ${ }^{11}$

\section{STATISTICAL ANALYSIS}

The trial was designed to have a statistical power of at least 90 percent to detect a 13 percent relative risk reduction in the primary end point with enoxaparin and used an event-driven approach. We estimated that randomization of approximately 21,000 patients would be required to yield the target of 2080 events.

All efficacy comparisons were analyzed according to the intention-to-treat principle. The analysis of the primary efficacy end point included all primary efficacy end points known to have occurred through 30 days after randomization and in the database that was locked on January 27,2006 . We prospectively planned to summarize events occurring after day 30 that were identified on the visit at day 30 (range, day 31 to 38 ) in a 6-month study report. The chi-square test was used to compare the primary and secondary end points in the two treatment groups. A log-rank test was also performed. All safety analyses were performed according to the treatment actually received by the patient.

An independent data and safety monitoring board monitored efficacy and safety. Prespecified interim analyses for efficacy and safety were con- 
ducted after approximately 25 percent, 50 percent, and 75 percent of the total targeted number of primary end-point events had occurred, according to the Lan-DeMets type of O'BrienFleming stopping boundary. The critical two-sided $\mathrm{P}$ value for the final analysis of the primary efficacy end point, after correction for interim analyses, was 0.043 . A P value of less than 0.05 was the threshold for nominal significance for all other end points.
The trial was designed as a collaborative effort between members of the steering committee and the sponsor, Sanofi-Aventis. The data were collected by a contract research organization (Quintiles). The raw database was provided by the sponsor to members of the TIMI Study Group. The prespecified and exploratory analyses were carried out independently by the TIMI Study Group (whose members wrote this report and take responsibility for the data) as well as the sponsor.

\begin{tabular}{|c|c|c|c|}
\hline Characteristic & $\begin{array}{l}\text { Enoxaparin } \\
(\mathrm{N}=10,256)\end{array}$ & $\begin{array}{l}\text { Unfractionated Heparin } \\
\qquad(\mathrm{N}=10,223)\end{array}$ & $\begin{array}{c}P \\
\text { Value }\end{array}$ \\
\hline Age $-y r$ & & & 0.35 \\
\hline Median & 59 & 60 & \\
\hline Interquartile range & $51-69$ & $51-69$ & \\
\hline Age $\geq 75 \mathrm{yr}-$ no. (\%) & $1241(12.1)$ & $1291(12.6)$ & 0.25 \\
\hline Male sex — no. (\%) & $7841(76.5)$ & $7855(76.8)$ & 0.52 \\
\hline White race — no./total no. (\%) & $8935 / 10,255(87.1)$ & $8920 / 10,223(87.3)$ & 0.79 \\
\hline Weight — kg & & & 0.22 \\
\hline Median & 76 & 76 & \\
\hline Interquartile range & $68-86$ & $68-85$ & \\
\hline Hypertension — no./total no. (\%) & $4505 / 10,128(44.5)$ & $4401 / 10,105(43.6)$ & 0.18 \\
\hline Hyperlipidemia — no./total no. (\%) & $1462 / 7979(18.3)$ & $1455 / 7990(18.2)$ & 0.85 \\
\hline Current smoker — no./total no. (\%) & $4855 / 10,254(47.3)$ & $4837 / 10,215(47.4)$ & 0.99 \\
\hline Diabetes mellitus — no./total no. (\%) & $1545 / 10,145(15.2)$ & $1515 / 10,104(15.0)$ & 0.64 \\
\hline Prior myocardial infarction — no./total no. (\%) & $1349 / 10,214(13.2)$ & $1310 / 10,190(12.9)$ & 0.46 \\
\hline Prior angina pectoris — no./total no. (\%) & $2864 / 10,179(28.1)$ & $2851 / 10,166(28.0)$ & 0.88 \\
\hline $\begin{array}{l}\text { Prior percutaneous coronary intervention - } \\
\text { no./total no. (\%) }\end{array}$ & $340 / 10,244(3.3)$ & $320 / 10,217(3.1)$ & 0.45 \\
\hline Anterior myocardial infarction — no./total no. (\%) & $4439 / 10,176(43.6)$ & $4494 / 10,157(44.2)$ & 0.37 \\
\hline Long-term treatment with aspirin — no./total no. (\%) & $1396 / 10,231(13.6)$ & $1356 / 10,205(13.3)$ & 0.45 \\
\hline $\begin{array}{l}\text { Unfractionated heparin within } 3 \mathrm{hr} \text { before randomization } \\
\quad \text { - no./total no. (\%) }\end{array}$ & $1634 / 10,255(15.9)$ & $1608 / 10,223(15.7)$ & 0.69 \\
\hline $\begin{array}{l}\text { LMWH within } 7 \text { days before randomization - } \\
\text { no./total no. (\%) }\end{array}$ & $43(0.4)$ & $50(0.5)$ & 0.46 \\
\hline Creatinine clearance $-\mathrm{ml} / \mathrm{min}$ & & & 0.23 \\
\hline Median & 82.3 & 82.0 & \\
\hline Interquartile range & $63.6-104.6$ & $63.1-104.2$ & \\
\hline \multicolumn{4}{|l|}{ Killip class - no. (\%) } \\
\hline 1 & $9098(88.8)$ & $9078(88.8)$ & 0.92 \\
\hline II & $1049(10.2)$ & $1036(10.1)$ & \\
\hline III & $94(0.9)$ & $99(1.0)$ & \\
\hline IV & $6(0.1)$ & $8(0.1)$ & \\
\hline Data missing & $9(0.1)$ & $2(<0.1)$ & \\
\hline
\end{tabular}




\section{RESULTS}

A total of 20,506 patients underwent randomization, of whom 20,479 were included in the intention-to-treat population; they were well matched for baseline characteristics (Table 1). The profile of their characteristics was similar to that seen in contemporary trials of interventions for ST-elevation myocardial infarction. The treatment groups were well matched with respect to concomitant therapy with other guideline-recommended treatments, such as aspirin, beta-blockers, and inhibitors of the renin-angiotensin system; the majority of patients received all these treatments.

A fibrinolytic agent was administered to 99.7 percent of patients, with 79.5 percent receiving a fibrin-specific agent and 20.2 percent receiving streptokinase (Table 1). The median time from the onset of symptoms to the start of fibrinolytic therapy was 3.2 hours.

A total of 15.8 percent of patients had received open-label unfractionated heparin in the three hours preceding randomization, and 0.5 percent had received low-molecular-weight heparin in the seven days preceding randomization (Table 1). Study drug was administered in a blinded fashion to 99.2 percent of patients, with 97.1 percent receiving it within 30 minutes after the start of fibrinolytic therapy.

As anticipated by the protocol design, treat-

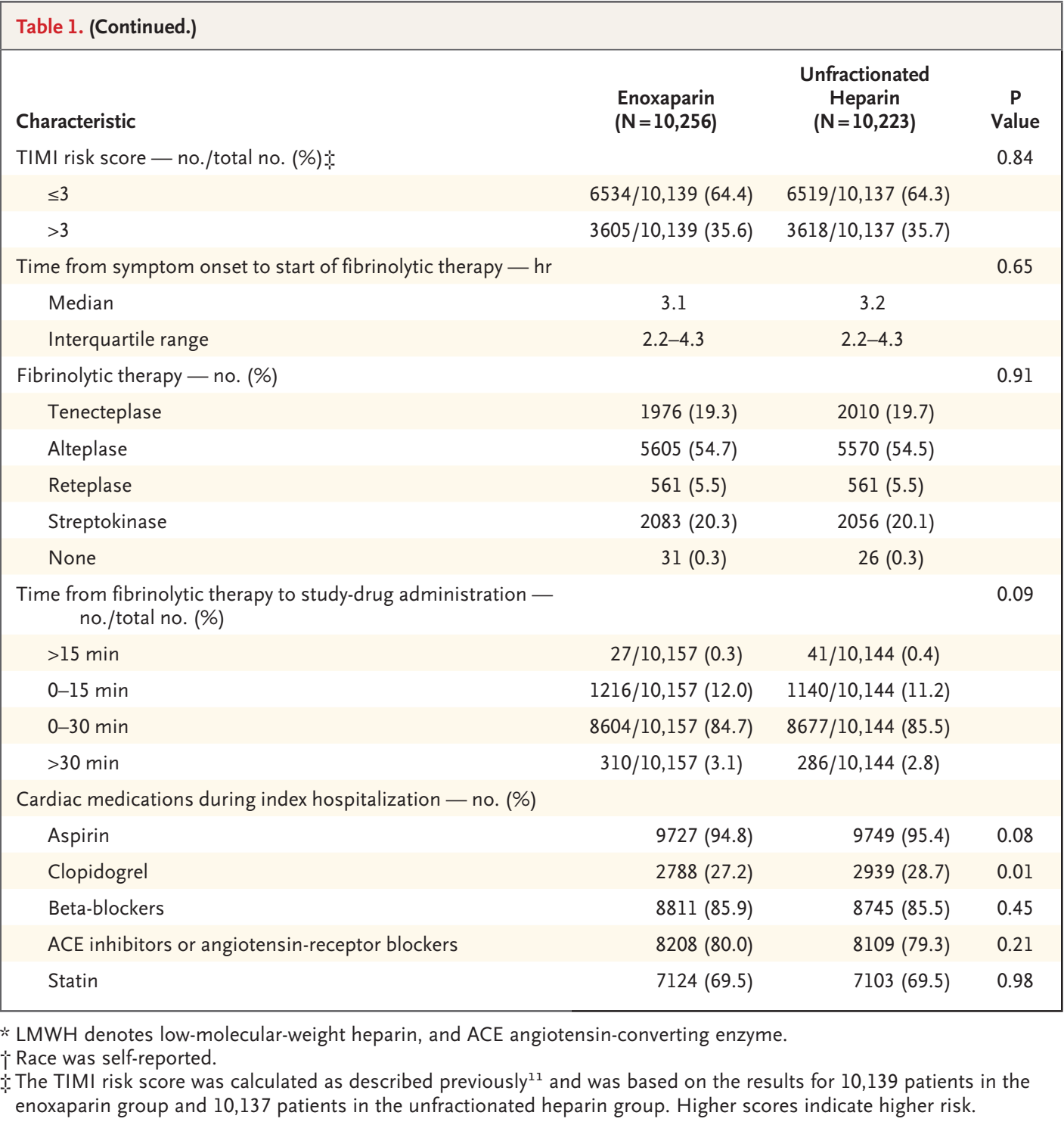




\begin{tabular}{|c|c|c|c|c|}
\hline \multirow[t]{2}{*}{ Outcome } & $\begin{array}{c}\text { Enoxaparin } \\
(N=10,256)\end{array}$ & $\begin{array}{c}\text { Unfractionated } \\
\text { Heparin } \\
(\mathrm{N}=10,223)\end{array}$ & $\begin{array}{l}\text { Relative Risk } \\
\text { (95\% CI) }\end{array}$ & P Value \\
\hline & \multicolumn{2}{|c|}{ number (percent) } & & \\
\hline \multicolumn{5}{|l|}{ Outcome at $48 \mathrm{hr}$} \\
\hline Death or nonfatal MI & $478(4.7)$ & $531(5.2)$ & $0.90(0.80-1.01)$ & 0.08 \\
\hline Death & $383(3.7)$ & $390(3.8)$ & $0.98(0.85-1.12)$ & 0.76 \\
\hline Nonfatal MI & $95(0.9)$ & $141(1.4)$ & $0.67(0.52-0.87)$ & 0.002 \\
\hline Urgent revascularization & $74(0.7)$ & $96(0.9)$ & $0.77(0.57-1.04)$ & 0.09 \\
\hline Death, nonfatal MI, or urgent revascularization & $548(5.3)$ & $622(6.1)$ & $0.88(0.79-0.98)$ & 0.02 \\
\hline \multicolumn{5}{|l|}{ Outcome at 8 days } \\
\hline Death or nonfatal MI & $740(7.2)$ & $954(9.3)$ & $0.77(0.71-0.85)$ & $<0.001$ \\
\hline Death & $559(5.5)$ & $605(5.9)$ & $0.92(0.82-1.03)$ & 0.15 \\
\hline Nonfatal MI & $181(1.8)$ & $349(3.4)$ & $0.52(0.43-0.62)$ & $<0.001$ \\
\hline Urgent revascularization & $145(1.4)$ & $247(2.4)$ & $0.59(0.48-0.72)$ & $<0.001$ \\
\hline Death, nonfatal MI, or urgent revascularization & $874(8.5)$ & $1181(11.6)$ & $0.74(0.68-0.80)$ & $<0.001$ \\
\hline \multicolumn{5}{|l|}{ Outcome at 30 days } \\
\hline Primary efficacy end point (death or nonfatal MI) & $1017(9.9)$ & $1223(12.0)$ & $0.83(0.77-0.90)$ & $<0.001$ \\
\hline Death & $708(6.9)$ & $765(7.5)$ & $0.92(0.84-1.02)$ & 0.11 \\
\hline Nonfatal MI & $309(3.0)$ & $458(4.5)$ & $0.67(0.58-0.77)$ & $<0.001$ \\
\hline Urgent revascularization & $213(2.1)$ & $286(2.8)$ & $0.74(0.62-0.88)$ & $<0.001$ \\
\hline Death, nonfatal MI, or urgent revascularization & 1199 (11.7) & $1479(14.5)$ & $0.81(0.75-0.87)$ & $<0.001$ \\
\hline
\end{tabular}

* Nonfatal myocardial infarction (MI) indicates that a patient had a recurrent MI and had not died by the time shown. Urgent revascularization denotes episodes of recurrent myocardial ischemia (without infarction) that drove the clinical decision to perform coronary revascularization during the same hospitalization. ${ }^{11} \mathrm{Cl}$ denotes confidence interval.

ment with enoxaparin lasted a median of 7.0 days (defined as 24-hour intervals after randomization) (interquartile range, 4.5 to 7.5 ; 90 th percentile, 7.5 ) and treatment with unfractionated heparin lasted a median of 2.0 days (interquartile range, 2.0 to 2.2; 90th percentile, 3.2). The median duration of hospitalization for the study population was 10 days (interquartile range, 7 to 17). The qualifying infarction was treated with medical therapy alone in 74.3 percent of patients, a percutaneous coronary intervention in 23.0 percent (as rescue therapy in 2.8 percent and as an urgent or elective procedure in 20.2 percent), and coronary-artery bypass surgery in 2.8 percent of patients.

\section{EFFICACY END POINTS}

The primary end point was ascertained at 30 days in all but three patients in the intention-to-treat population. The rate of the primary efficacy end point (death or nonfatal myocardial infarction) was 9.9 percent in the enoxaparin group, as compared with 12.0 percent in the unfractionated heparin group (17 percent reduction in the relative risk, $\mathrm{P}<0.001$ ) (Table 2 and Fig. $1 \mathrm{~A}$ ). The beneficial effect of enoxaparin on the primary end point was consistent across key prespecified subgroups (Fig. 2). In addition, there was a significant treatment benefit of enoxaparin, as compared with unfractionated heparin, in patients who underwent percutaneous coronary intervention within 30 days after randomization (23 percent reduction in relative risk) or who were treated medically (16 percent reduction in relative risk, $\mathrm{P}=0.33$ for interaction). The treatment benefits of enoxaparin, evident for a number of efficacy outcomes, emerged at 48 hours, at which time there was a 33 percent reduction in the relative risk of nonfatal myocardial infarction, as compared with treatment with unfractionated heparin ( $\mathrm{P}=0.002)$ (Table 2).

At 30 days, the mortality rate was 7.5 percent in the unfractionated heparin group, as compared 
with 6.9 percent in the enoxaparin group $(\mathrm{P}=0.11)$ (Table 2). Enoxaparin significantly reduced the rate of recurrent nonfatal myocardial infarction (3.0 percent, vs. 4.5 percent in the unfractionated heparin group; 33 percent reduction in the relative risk; $\mathrm{P}<0.001$ ) (Table 2). Episodes of recurrent myocardial ischemia leading to urgent revascularization were significantly reduced, from 2.8 percent in the unfractionated heparin group to 2.1 percent in the enoxaparin group $(\mathrm{P}<0.001)$ (Table 2). As compared with unfractionated heparin, enoxaparin also significantly reduced the incidence of the main secondary end point of death, nonfatal myocardial infarction, or urgent revascularization (11.7 percent vs. 14.5 percent, $\mathrm{P}<0.001$ ) (Table 2 and Fig. 1B).

\section{SAFETY END POINTS}

The rates of TIMI major bleeding (including intracranial hemorrhage) at 30 days were 1.4 percent in the unfractionated heparin group and 2.1 percent in the enoxaparin group (absolute increase of 0.7 percentage point and 53 percent increase in the relative risk, $\mathrm{P}<0.001$ ) (Table 3). The rates of intracranial hemorrhage were 0.7 percent in the unfractionated heparin group and 0.8 percent in the enoxaparin group $(\mathrm{P}=0.14)$. The respective rates of minor bleeding and the composite of major or minor bleeding were 0.8 and 1.5 percentage points higher in the enoxaparin group than in the group given unfractionated heparin (relative risk, 1.41 and 1.47, respectively) (Table 3).

\section{NET CLINICAL BENEFIT}

The rates of all three prespecified net-clinicalbenefit composite end points were significantly lower at 30 days in the enoxaparin group than in the unfractionated heparin group (Table 4). Enoxaparin had a similar, beneficial effect on these end points, which are composites of efficacy and different aspects of safety (nonfatal disabling stroke, nonfatal major bleeding, and nonfatal intracranial hemorrhage). The range of reductions in the absolute event rates was 1.8 to 2.2 percentage points, corresponding to reductions in the relative risk of 14 to 18 percent $(\mathrm{P}<0.001$ for all comparisons).

\section{DISCUSSION}

Our results demonstrate that a strategy of administering enoxaparin throughout the index hospi-

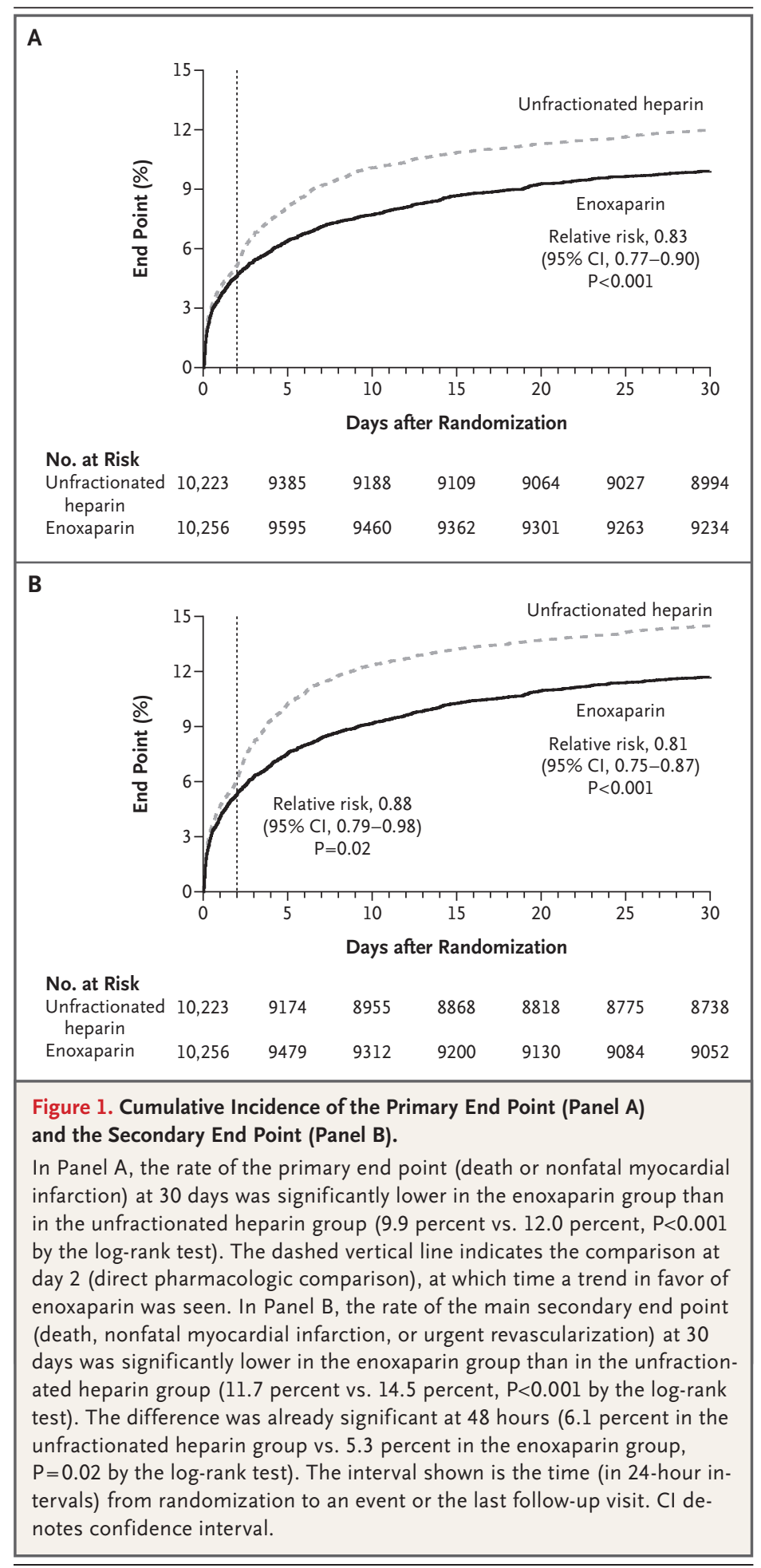

talization is superior to the current strategy of administering unfractionated heparin for 48 hours as adjunctive antithrombin therapy for patients with ST-elevation myocardial infarction who un- 


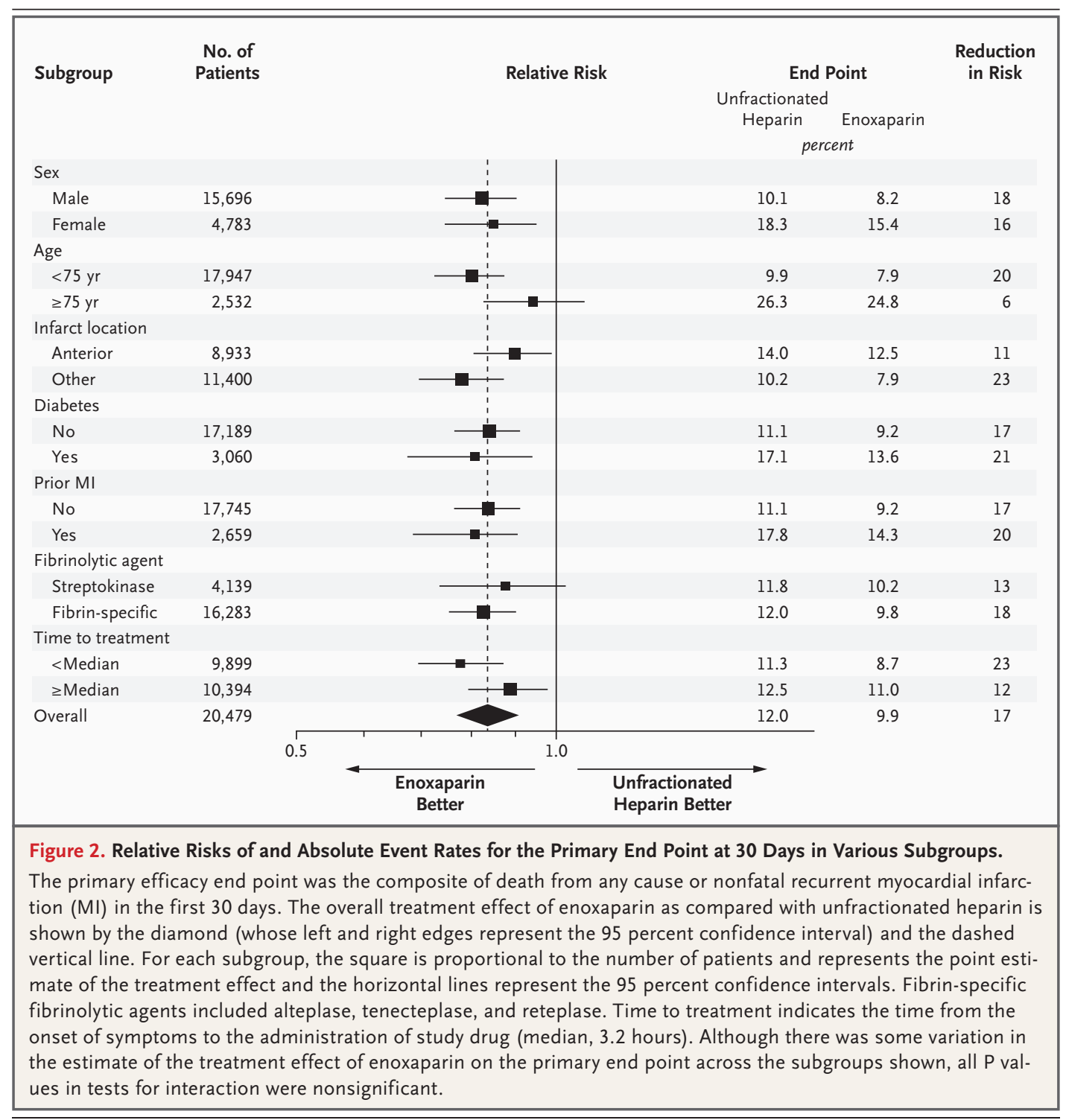

dergo pharmacologic reperfusion with a fibrinolytic agent. Although antithrombin agents have not been reported to enhance initial clot lysis, their use as part of a pharmacologic reperfusion regimen is associated with a higher rate of patency of the infarct artery hours to days after initial fibrinolytic therapy and a lower rate of recurrent myocardial infarction. ${ }^{14-16}$ After initially successful fibrinolysis, reocclusion of the infarct artery is associated with a near tripling of mortality. ${ }^{17-19}$ The risk of reocclusion is related to the underlying degree of stenosis and the residual thrombus. ${ }^{20-22}$

Three factors may have contributed to the treatment differences we observed: a superior antithrombotic effect of enoxaparin, a longer duration of treatment with enoxaparin, and possibly, a rebound increase in thrombotic events after the discontinuation of unfractionated heparin, as suggested by the shape of the curves in Figure 1. We are unable to determine definitively the relative contributions of each of these factors to the results observed.

The significant 33 percent reduction in the relative risk of myocardial reinfarction at 30 days with enoxaparin suggests that the antithrombotic effect of this agent is superior to that achieved with the currently recommended regimen of unfractionated heparin. We also observed a 26 percent reduction in the need for urgent revascularization at 30 days in the enoxaparin group (Table 2). The superior antithrombotic effect of enoxaparin may 


\begin{tabular}{|c|c|c|c|c|}
\hline Outcome & $\begin{array}{l}\text { Enoxaparin } \\
(\mathrm{N}=10,176)\end{array}$ & $\begin{array}{c}\text { Unfractionated } \\
\text { Heparin } \\
(\mathrm{N}=10,151)\end{array}$ & $\begin{array}{c}\text { Relative Risk } \\
\text { (95\% CI) }\end{array}$ & P Value \\
\hline \multicolumn{5}{|c|}{ number (percent) } \\
\hline \multicolumn{5}{|l|}{ Outcome at $48 \mathrm{hr}$} \\
\hline Major bleeding (including ICH) & $146(1.4)$ & $101(1.0)$ & $1.44(1.12-1.86)$ & 0.004 \\
\hline $\mathrm{ICH}$ & $68(0.7)$ & $56(0.6)$ & $1.21(0.85-1.72)$ & 0.29 \\
\hline Minor bleeding & $159(1.6)$ & $122(1.2)$ & $1.30(1.03-1.64)$ & 0.028 \\
\hline Major or minor bleeding & $301(3.0)$ & $219(2.2)$ & $1.37(1.15-1.63)$ & $<0.001$ \\
\hline \multicolumn{5}{|l|}{ Outcome at 8 days } \\
\hline Major bleeding (including ICH) & $185(1.8)$ & $124(1.2)$ & $1.49(1.19-1.87)$ & $<0.001$ \\
\hline $\mathrm{ICH}$ & $81(0.8)$ & $62(0.6)$ & $1.30(0.94-1.81)$ & 0.11 \\
\hline Minor bleeding & $236(2.3)$ & $162(1.6)$ & $1.45(1.19-1.77)$ & $<0.001$ \\
\hline Major or minor bleeding & $415(4.1)$ & $279(2.7)$ & $1.48(1.28-1.72)$ & $<0.001$ \\
\hline \multicolumn{5}{|l|}{ Outcome at 30 days } \\
\hline Major bleeding (including $\mathrm{ICH}$ ) & $211(2.1)$ & $138(1.4)$ & $1.53(1.23-1.89)$ & $<0.001$ \\
\hline $\mathrm{ICH}$ & $84(0.8)$ & $66(0.7)$ & $1.27(0.92-1.75)$ & 0.14 \\
\hline Minor bleeding & $260(2.6)$ & $184(1.8)$ & $1.41(1.17-1.70)$ & $<0.001$ \\
\hline Major or minor bleeding & $464(4.6)$ & $315(3.1)$ & $1.47(1.28-1.69)$ & $<0.001$ \\
\hline \multicolumn{5}{|c|}{$\begin{array}{l}\text { Safety events were assessed in the treated population. There were } 15 \text { patients in the safety population who were treatec } \\
\text { with study drug without undergoing randomization. Bleeding was assessed according to the TIMI criteria. A total of } \\
37.9 \text { percent of patients in the enoxaparin group and } 31.9 \text { percent in the unfractionated heparin group who had a majo } \\
\text { bleeding episode died ( } P=0.25) \text {. In patients who had a major bleeding episode, the mortality rate at } 30 \text { days was } 0.8 \\
\text { percent in the enoxaparin group ( } 80 \text { of } 10,176) \text { and } 0.4 \text { percent in the unfractionated heparin group ( } 44 \text { of } 10,151 ; \\
P=0.001) \text {. Among the } 80 \text { deaths in the enoxaparin group, the primary cause was considered to be hemorrhagic in } 56 \\
\text { (70 percent), cardiovascular in } 19 \text { ( } 24 \text { percent), noncardiovascular in } 4 \text { ( } 5 \text { percent), and unknown in } 1 \text { ( } 1 \text { percent). } \\
\text { Among the } 44 \text { deaths in the unfractionated heparin group, the primary cause was considered to be hemorrhagic in } 34 \\
\text { ( } 77 \text { percent), cardiovascular in } 9 \text { ( } 20 \text { percent), and noncardiovascular in } 1 \text { ( } 2 \text { percent). In patients who had a nonfatal } \\
\text { intracranial hemorrhage, } 46.2 \text { percent ( }(12 \text { of } 26) \text { in the enoxaparin group and } 62.1 \text { percent ( } 18 \text { of } 29) \text { in the unfraction- } \\
\text { ated heparin group had a significant permanent neurologic disability }(P=0.24) \text {. }\end{array}$} \\
\hline
\end{tabular}

be explained, in part, by its greater ratio of antifactor Xa to anti-factor IIa activity, since the inhibition of a single molecule of factor Xa inhibits the downstream production of many thrombin molecules. ${ }^{10,23}$

The convenience of the subcutaneous route of administration was a factor in our decision to test a strategy of administering enoxaparin for the duration of the index hospitalization. Extended treatment with enoxaparin most likely contributed to a more sustained antithrombotic effect. It is notable that the rate of the main secondary end point of death, nonfatal myocardial infarction, or urgent revascularization was significantly lower in the enoxaparin group than in the unfractionated heparin group within 48 hours. Previous work failed to show that the infusion of unfractionated heparin for more than 48 hours prevents reocclusion of successfully reperfused infarct ar- teries in patients with ST-elevation myocardial infarction.1,2,24 Furthermore, no strategies for dealing with the possibility of rebound after the discontinuation of unfractionated heparin have been rigorously examined, and rebound may occur after treatment with unfractionated heparin regardless of the duration of the infusion. ${ }^{10}$

There was no significant increase in the rate of intracranial hemorrhage with enoxaparin therapy. There was, however, a significant increase in episodes of major bleeding. Although comparisons across trials are difficult because of the possible effect of differences in definitions of bleeding, the rates of major bleeding in both treatment groups were lower than those reported in a prior meta-analysis (in which the in-hospital rate of major bleeding was 3.3 percent with enoxaparin and 2.5 percent with unfractionated heparin). ${ }^{12}$ The low rate of use of open-label unfractionated 


\begin{tabular}{|c|c|c|c|c|}
\hline Outcome & $\begin{array}{l}\text { Enoxaparin } \\
(\mathrm{N}=10,256)\end{array}$ & $\begin{array}{c}\text { Unfractionated } \\
\text { Heparin } \\
(\mathrm{N}=10,223)\end{array}$ & $\begin{array}{l}\text { Relative Risk } \\
\quad(95 \% \mathrm{CI})\end{array}$ & P Value \\
\hline \multicolumn{5}{|c|}{ number (percent) } \\
\hline $\begin{array}{l}\text { Death, nonfatal MI, or nonfatal dis- } \\
\text { abling stroke }\end{array}$ & $1038(10.1)$ & $1260(12.3)$ & $0.82(0.76-0.89)$ & $<0.001$ \\
\hline $\begin{array}{l}\text { Death, nonfatal MI, or nonfatal major } \\
\text { bleeding }\end{array}$ & $1128(11.0)$ & 1305 (12.8) & $0.86(0.80-0.93)$ & $<0.001$ \\
\hline $\begin{array}{l}\text { Death, nonfatal MI, or nonfatal intra- } \\
\text { cranial hemorrhage }\end{array}$ & $1040(10.1)$ & $1250(12.2)$ & $0.83(0.77-0.90)$ & $<0.001$ \\
\hline
\end{tabular}

* The composite end points listed were calculated in a hierarchical fashion in the order shown, and equivalent weight was assigned to each of the three elements. $\mathrm{Cl}$ denotes confidence interval, and $\mathrm{MI}$ myocardial infarction.

heparin before randomization, the use of conservative dosing strategies, and avoidance of double anticoagulation through the use of masked study drug to support percutaneous coronary interventions may have contributed to the low bleeding rates we observed.

Our findings indicate that treatment with enoxaparin throughout the index hospitalization for ST-elevation myocardial infarction is superior to the current strategy of infusing unfractionated heparin for 48 hours as adjunctive antithrombin therapy to fibrinolysis. For every 1000 patients treated with the enoxaparin strategy, there would be 15 fewer nonfatal reinfarctions, 7 fewer episodes of urgent revascularization, and 6 fewer deaths, at the cost of 4 additional episodes of nonfatal major bleeding (with no increase in the num- ber of nonfatal intracranial hemorrhages). It is our judgment that despite the increase in episodes of major bleeding, the early and sustained reduction in ischemic events and the balance of efficacy and safety, as assessed by three net-clinical-benefit end points, demonstrate the advantage of the regimen of enoxaparin over 48 hours of unfractionated heparin as the adjunctive antithrombin regimen to support fibrinolysis.

Supported by a research grant from Sanofi-Aventis to the TIMI Study Group.

Drs. Antman, Morrow, López-Sendón, White, Fox, and Braunwald report having received research grant support from SanofiAventis, having received lecture fees from Sanofi-Aventis, and having served on paid advisory boards for Sanofi-Aventis. Drs. Ruda, Sadowski, Budaj, and Guneri and Ms. McCabe and Ms. Murphy report having received research grant support from Sanofi-Aventis. Dr. Jiang is an employee of Sanofi-Aventis. No other potential conflict of interest relevant to this article was reported.

APPENDIX

The participants in the ExTRACT-TIMI 25 Study are as follows: TIMI Study Group, Brigham and Women's Hospital, Boston - E. Braunwald (study chair), E.M. Antman (principal investigator), C. McCabe, D.A. Morrow, S.A. Murphy, S. McHale; Sanofi-Aventis, Bridgewater, N.J. (sponsor) - F. Jiang, C. Gaudin, P. Chew, L. Cui, L. Teoh, S. Fontecave, J. Cortez, K. Giordano, R. Merino, R. Smith, T. Luo, S. Martin, G. Guironnet, C. Akhoundi, L. Siffre, C. Nouck-A-Nwal; Data Coordinating Center - K. Long (Quintiles); Centralized Randomization - R. Luthra, K. Hatfield (ClinPhone); Data Management for Activated Partial-Thromboplastin Time - M. Sabbe (Covance); Executive Committee - E. Braunwald, H. White, K.A.A. Fox; Steering Committee - E. Braunwald, E.M. Antman, C. McCabe, D.A. Morrow, S.A. Murphy, S. McHale; Argentina - E. Gurfinkel; Australia - P. Aylward; Austria - K. Huber; Belarus - L. Polonetsky; Belgium - J. Col; Brazil - J.C. Nicolau; Romania - M. Dorobantu; Bulgaria - N. Gotcheva; Canada - A. Turpie, P. Theroux, A. Langer; Chile - R. Corbalan; China - R. Gao; Croatia - M. Bergovec; Estonia — J. Voitk; France — G. Montalescot; Germany — D. Gulba; Hong Kong, China - K.S. Woo; Hungary - E. Ostor; Israel - H. Hod; Italy - D. Ardissino; Korea - K.-B. Seung; Latvia - U. Kalnins; Malaysia — D. Robaayah Zambahari; Mexico — A. Garcia Castillo; the Netherlands - P. Molhoek, F. Verheught; New Zealand - H. White; Norway - K. Dickstein; Poland - Z. Sadowski, A. Budaj; Portugal - J. Morais; Russia - M. Ruda, S. Varshavsky; Singapore - H. Cheem; Slovakia - T. Duris; South Africa — A. Dalby; Spain — J. López-Sendón; Sweden — S. Agewall; Switzerland — M. Pfisterer; Turkey — S. Guneri; Ukraine - A. Parkhomenko; United Kingdom - A.J. Jacob, K.A.A. Fox; United States - J. Alpert, R. Califf, M. Cohen; Data and Safety Monitoring Board: F. Van de Werf (chair), D. DeMets, D. Julian, J. Rouleau, J. Ward Kennedy, J. Anderson, K. Lee, S. Sapp; Clinical Centers and Principal Investigators (in descending order of patient enrollment) - Russian Federation: V. Shulman, V. Lusov, A. Vishnevskiy, A. Duda, P. Dovgalevsky, V. Mkrtchian, M. Boyarkin, O. Barbarash, Y. Gabinsky, Y. Shvarts, D. Belenky, S. Shalaev, V. Yakusevich, M. Glezer, V. Kostenko, V. Markov, M. Ruda, I. Bokarev, S. Tereschenko, S. Yakushin, O. Khrustalev, V. Moiseev, V. Barbarich, O. Lapin, N. Gratsiansky, M. Baluda, V. Shmyrova, A. Panov, G. Aroutiounov, R. Stryuk, L. Katelnitskaya, D. Zateyschikov, E. Volkova, V. Tyrenko, A. Shpektor, S. Boldueva, Y. Grinstein, G. Zalevsky, A. Petrov, G. Storozhakov, M. Arkhipov, N. Zubanov; Poland: A. Drzewiecki, J. Kopaczewski, M. Krzeminska-Pakula, M. Bronisz, A. Gieroba, K. Jaworska, M. Ogorek, K. Zmudka, T. Kawka-Urbanek, K. Wrabec, E. Zinka, P. Kolodziej, J. Tarchalski, M. Ujda, M. Skura, P. Burduk, K. Kuc, J. Kuzniar, J. Mormul, M. Janion, T. Czerski, W. Ruminski, P. Achremeczyk, A. Lugowski, D. Wojciechowski, A. Kleinrok, M. Trusz-Gluza, M. Goszczynska, R. Sciborski, R. Szelemej; Spain: J.A. Cambronero, J. Froufe, J. Ortega, S. Nicolas, J. Blanco Varela, H. Pérez Hernández, L. Ramos, J. Martín, P. Pabón Osuna, A.J. Montón, R. Claramonte, P. Marco, A. Loma Osorio, M. Ruano, E. Esplugas, A. Ricart, R. Rubio Sanz, J. Torres Ruiz, I. Antorrena- 
Maranda, M. Fiol Sala, J. Nava, A. Lesmes, G. Pérez Planelles, V. López, P. Galdos, M. Piqué, V. Valle, V. Valentín, J. Bassaganyas, A. Pérez Garrido, J. Masip, J. Merino, R. Fernández-Fernández, A. Carrillo, R. Vicho, J. Bayón, J. San José, J. Bruguera, F. Taboada, A. Rovira, J. Arias, F. Bellot, F. Ortiz; Turkey: E. Diker, A. Oguzhan, M. Yesil, S. Guneri, M. Demirtas, C. Turkoglu, T. Kurum, A. Aydinlar, B. Timuralp, F. Ertas, A. Vural, H. Senocak, S. Celik, H. Muderrisoglu, M. Aksoy, A. Cengel, N. Cam, G. Cin, D. Ural, M. Baltali; Israel: N. Roguin, O. Kracoff, B. Lewis, T. Rosenfeld, Y. Rozenman, A. Roth, D. David, L. Reisin, E. Kaluski, S. Matetzky, H. Hammerman, S. Meisel, D. Zahger, J. Balkin; Ukraine: I. Krayz, O. Koval, K. Amosova, V. Tseluyko, A. Parhomenko, O. Karpenko, A. Fainyk, V. Netyazhenko, V. Syvolap, Y. Dykun, L. Kononenko, B. Goloborodko; India: N.K. Reddy, J.P.S. Sawhney, P.K. Grant, S.S. Ramesh, J.S. Bhuvaneshwaran, B. Ramesh Babu, V.K. Puri, T. Alexander, A. Mullasari, T. Nair, S.S. Iyengar, R.P.S. Bharadwaj, K. Parikh, S. Rane; the Netherlands: G.C.M. Linssen, P. Bendermacher, E. Van Nes, A.G. Boehmer, M. Kofflard, B. Hamer, M.C.G. Daniels, A. Derks, R.F. Veldkamp, A.H. Liem, R.M. Tjon Joe Gin, M. Van Hessen, J. Tans, W.J.T. Jap Tjeon San, P.R.M. Van Dijkman, M.P. Freericks, P. Zijnen, H.J.M. Thijssen, A. Withagen, P.R. Nierop, J.H.M. Schreur, M. Van Der Linden, A.H. Herweijer, H.A. Werner, B.J. Van Den Berg, P. Van Rossum, G.J. Van Beek, R.M. Robles De Medina, P. Van Der Meer, L.H. Takens, P. Dunselman, R. Ciampricotti, T. Van Loenhout; United Kingdom: A. Jacob, R. Cowell, C. Francis, M. Brack, R. Senior, P.R. Wilkinson, I.R. Starkey, J. Adgey, K.A.A. Fox, R. Wray, N. Patel, R. Ahmad, M. Farrer, S. Talwar, N. Herity, K. Jennings, R. Aggarwal, B. McClements, M. Al-Khafaji, J. Forfar, A. Pell, J. Rowley, A. Bridges, S. Saltissi, J.D. Stephens, D. Hackett, S. Lindsay, W. Grabau, A. Alwail, A. Rozkovec, A. Rae, C. Lawson, M. Pye, K. Morris, A.O. Molajo, M. Hargreaves, R. Mansfield, J. Doig, P. Lewis, A. Nasser, H. Papaconstantinou, B. Vallance, R. Andrews, M. Been, S. Virk, P. Wong, R. Wilcox, P. Stubbs, R. Grocott-Mason, S. Gupta, D. Bruce, B. Saeed, J. Dhawan, C. Plummer, G. Lip, I. Hudson, P.R. Walker, T. Mathew, S.J. Hutchison, W.J. Penny, M. Pitt, P. Weissberg, I. Findlay, S. Cross, L. Bhatia; Italy: G. Corsini, A. Vetrano, P. Terrosu, V. Ciconte, C. Astarita, O. Silvestri, L. Fattore, G. Ruggeri, A. Fiscella, M. Comito, M. Barbiero, F. Miccoli, M.G. Carmina, G. Giorgi, D. Banda, A. Capucci, I. De Luca, S. Severi, F. Cariello, M. Brignole, A. Grieco, M. Di Biase, R. Evola, A. Rolli, T. Morgera, P. Maras, S. Ricci, M. Orlandi, B. Tuccillo, M. Onofri, F. Melandri, R. Delfino, F. Arrigo, L. Vasquez, A. Bongo, C. Cernigliaro, P. Bellotti, S. Pirelli, C. Barletta, E. Renaldini, N. Ciampani, G. Altamura, S. Domenicucci, F. Tartagni; Romania: M. Cinteza, M. Vintila, M. Dorobantu, C. Georgescu, D. Ionescu, C.F. Pop, R. Capalneanu, C. Macarie, R. Mariana; Bulgaria: S. Milanov, A. Popov, M. Tzekova, N. Penkov, B. Chompalova, V. Hergeldjieva, M. Grigorov, S. Denchev, H. Kojuharov, I. Perchev, N. Gotcheva; Hungary: S. Timar, Z. Kovacs, M. Sereg, A. Katona, C. Toth, Z. Bogdan, A. Matoltsy, S. Amer, I. Horvath, A. Kovacs, F. Poor, E. Kalo, C. Dezsi, I. Inczeffy, I. Preda; New Zealand: D. Friedlander, A. Hamer, H. Hart, J. Hedley, R. Luke, T. O’Meeghan, R. Rankin, D. Scott, A. Aitken, J. Tisch, H. White, G. Wilkins, I. Ternouth, M. Hills; Chile: R. Lamich, F. Gutierrez, O. Pedemonte, G. Arriagada, F. Albornoz, S. Urgarte, F. Cardenas, J. Escobar, C. Bugueno, E. Chavez, G. Illanes, R. Corbalan, P. Sanhueza; Brazil: P. Rossi, J. Miranda Abrantes, O. Dutra, C. Gun, L. Maia, J. Quinaglia, E. Silva, V. Golin, A. Timermann, J. Marin Neto, L.C. Bodanese, O. Coelho, G. Greque, P. Nogueira, J. Braga, A. Rabelo Alves, Jr., A. Carvalho, C. Serrano, J. Saraiva, M. Baptista Filho, D. De Albuquerque; China: Y. Han, S. Lv, S. Jia, Q. Wu, X. Yang, H. Ma, B. Sun, M. Wei, D. Hu, B. Zhao, W. Gao, J. Ge, W. Fan, J. Chen, Q. Dang, R. Gao, Y. Huo, B. Yu, W. Zhu, L. Gai, W. Li, X. Li, X. Zhou, G. Zhu; Argentina: S. Macin, G. Bortman, A. Caccavo, M. Halac, J. Beloscar, O. Caruso, E. Gurfinkel, S. Chekherdemian, H. Luquez, D. Agranatti, R. Ahuad Guerrero, R. Badra, M. Hominal, H. Torres, A. Campo, C. Pellegrini, L. Girotti, M. Litvak Bruno, I. Chaves, C. Estrada, M. Russo, J. Bono, R. Perez de la Hoz; Slovakia: V. Spisak, J. Kmec, T. Duris, A. Banikova, V. Macek, J. Hasilla, O. Herman; South Africa: J. Bayat, I. Ebrahim, A. Doubell, R. Naidu, P. Blomerus, F. Maritz, L. Van Zyl, L. Steingo, A. Dalby, T. Mabin, E. Lloyd, R. Routier, J. Steyn, D. Duncan, A. Da Silva, T. Venter, J. Patel, M. Seeber; Australia: J. Counsell, D. Henderson, C. Hii, J. Waites, P. Carroll, M. Schoeman, B. Singh, A. Whelan, P. Thompson, G. Aroney, D. Chew, D. Cross, P. Boyd, J. Strickland, J. Horowitz, S. David, S. Coverdale, T. Smyth; Mexico: U. Juarez, G. Lopez-Ramos, A. Nacoud, A. Mireles, J. Carrillo, I. Hernandez, F. Petersen, A. Garcia, M. Zuniga, P. Hinojosa-Pineda; Republic of Korea: J.H. Yoon, S.J. Kim, M.H. Jeong, K.B. Seung, Y.J. Kim, K.Y. Chang, K.S. Park, H.M. Kwon, E.J. Kim, S.C. Chae, W.S. Chung, M.Y. Lee, B.H. Oh, M.C. Cho; Croatia: K. Catipovic, P. Samardzic, A. Jovic, M. Padovan, B. Jaksic, D. Trsinski, G. Milicevic; Greece: J. Nanas, A. Zacharoulis, T. Apostolou, E. Papasteriadis, D. Hatseras, F. Triposkiadis, T. Kolettis, G. Louridas, V. Votteas, C. Papadopoulos, C. Stefanadis, P. Vardas; Germany: W. Leupolz, D. Buchholz, J. Epping, R. Zotz, B. Pfaffenbach, T. Dorsel, E. Eggers, G. Mertes, J. Ontyd, G. Lockert, B. Linder, R.D. Beythien, A. Klamann, G. Claus, P. Gaudron, T. Heyer, V. Hossmann, D. Gulba; Canada: P. Tan, M. Heffernan, R.K. Bhargava, W. Hui, L. Winkler, M. Senaratne, D. Kincade, J. Javier, S. Vizel, J. Graham, J. Stimac, D. Fitchett, S. Pallie, P. Smylie, M. Shuster; Thailand: A. Sukonthasarn, P. Sritara, D. Tresukosol, W. Buddhari, C. Piamsomboon; Belgium: D. El Allaf, A. De Meester, F. Foret, R. Popeye, F. Marenne, B. Pirenne, F. De Leener; Estonia: J. Voitk, V. Vahula, A. Reinold; Malaysia: S. Hian, R. Zambahari, W.P. Chong, J. Sinnadurai, C.Y. Lee, K. Yusoff, P. Mahadasa; Portugal: A. Aleixo, M.A. Pereira, L. Bernardino, M.V. Gomes, L. Martins, M.G. Silva, I. Moreira, L. Gomes, J. Puig, J.A. Santos; Austria: K. Huber, E. Grafl, A. Dalos, W. Schellnegger, G. Puhr, B. Bauer, H. Pristautz, P. Bratusch-Marrain, G. Gaul, H. Frank, A. Hartweger; Sweden: V. Roussine, S. Agewall, M. Lycksell, L. Lundkvist, S. Stalnacke, C. Stafberg, D. Hagstrom; Switzerland: H. Zender, T. Moccetti, A. Gallino, A. Pagnamenta, H.P. Voegelin, P. Ballmer; Belarus: L. Polonetsky, N. Soroka, A. Mrochak, A. Bulgak; United States: E. Lader, J. Gelormini, G. Miller, B. Patel, H. Morse, H. Chandna, C. Boylan, R. Morris, H. Mueller; Lithuania: V. Jokas, J. Brazdzionyte, B. Petrauskiene; Norway: T. Graven, A. Dimmen, T.M. Omland, F. Erchinger, T.I. Stakkevold; Latvia: G. Dormidontova, U. Kalnins, M. Keisa; Lebanon: S. Lawand, R. Kassab, A. Abchi; Singapore: Q.W. Yong, H.C. Tan; Finland: S. Voutilainen, K. Peuhkurinen, M. Huttunen, S. Utriainen; Uruguay: F. Di Leoni, J. Patriti, S. Bentancurt, A. Cataldo; Ireland: K. Daly, M. Conway, H. McCann, D. Mulcahy; Hong Kong, China: W.H. Chen, S.K. Kwong; Jordan: M. Nemri; France: N. Benazza.

\section{REFERENCES}

1. Antman EM, Anbe DT, Armstrong $\mathrm{PW}$, et al. ACC/AHA guidelines for the management of patients with ST-elevation myocardial infarction: a report of the American College of Cardiology/American Heart Association Task Force on Practice Guidelines (Committee to Revise the 1999 Guidelines for the Management of Patients With Acute Myocardial Infarction). Bethesda, Md.: American College of
Cardiology Foundation, 2004. (Accessed March 13, 2006, at http://www.acc.org/ clinical/guidelines/stemi/index.pdf.)

2. Van de Werf F, Ardissino D, Betriu A, et al. Management of acute myocardia infarction in patients presenting with ST segment elevation. Eur Heart J 2003;24:28 66.

3. Gruppo Italiano per lo Studio della Sopravvivenza nell'Infarto Miocardico.
GISSI-2: a factorial randomised trial of alteplase versus streptokinase and heparin versus no heparin among 12,490 patients with acute myocardial infarction. Lancet 1990;336:65-71.

4. ISIS-3 (Third International Study of Infarct Survival) Collaborative Group. ISIS-3: a randomised comparison of streptokinase vs tissue plasminogen activator vs anistreplase and of aspirin plus hepa- 
rin vs aspirin alone among 41,299 cases of suspected acute myocardial infarction. Lancet 1992;339:753-70.

5. The GUSTO Investigators. An international randomized trial comparing four thrombolytic strategies for acute myocardial infarction. N Engl J Med 1993;329:673 82.

6. The Global Use of Strategies to Open Occluded Coronary Arteries (GUSTO) IIb Investigators. A comparison of recombinant hirudin with heparin for the treat ment of acute coronary syndromes. $\mathrm{N}$ Engl J Med 1996;335:775-82

7. Antman EM. Hirudin in acute myocardial infarction: Thrombolysis and Thrombin Inhibition in Myocardial Infarction (TIMI) 9B trial. Circulation 1996 94:911-21.

8. The Continuous Infusion versus Double-Bolus Administration of Alteplase (COBALT) Investigators. A comparison of continuous infusion of alteplase with double-bolus administration for acute myocardial infarction. N Engl J Med 1997; 337:1124-30.

9. The Global Use of Strategies to Open Occluded Coronary Arteries (GUSTO III Investigators. A comparison of reteplase with alteplase for acute myocardial in farction. N Engl J Med 1997;337:1118-23.

10. Antman EM. The search for replacements for unfractionated heparin. Circulation 2001;103:2310-4

11. Antman EM, Morrow DA, McCabe $\mathrm{CH}$, et al. Enoxaparin versus unfractionated heparin as antithrombin therapy in patients receiving fibrinolysis for ST-elevation myocardial infarction: design and rationale for the Enoxaparin and Thrombolysis Reperfusion for Acute Myocardia Infarction Treatment-Thrombolysis In
Myocardial Infarction study 25 (ExTRACTTIMI 25). Am Heart J 2005;149:217-26.

12. Eikelboom JW, Quinlan DJ, Mehta SR, Turpie AG, Menown IB, Yusuf S. Unfractionated and low-molecular-weight heparin as adjuncts to thrombolysis in aspirintreated patients with ST-elevation acute myocardial infarction: a meta-analysis of the randomized trials. Circulation 2005; 112:3855-67.

13. Wallentin L, Goldstein P, Armstrong PW, et al. Efficacy and safety of te necteplase in combination with the lowmolecular-weight heparin enoxaparin or unfractionated heparin in the prehospital setting: the Assessment of the Safety and Efficacy of a New Thrombolytic Regimen (ASSENT)-3 PLUS randomized trial in acute myocardial infarction. Circulation 2003;108:135-42

14. Topol EJ, George BS, Kereiakes DJ, et al. A randomized controlled trial of intravenous tissue plasminogen activator and early intravenous heparin in acute myocardial infarction. Circulation 1989;79: 281-6.

15. Hsia J, Hamilton WP, Kleiman $N$ Roberts R, Chaitman BR, Ross AM. A comparison between heparin and low-dose aspirin as adjunctive therapy with tissue plasminogen activator for acute myocardial infarction. N Engl J Med 1990;323: 1433-7.

16. de Bono DP, Simoons ML, Tijssen J, et al. Effect of early intravenous heparin on coronary patency, infarct size, and bleeding complications after alteplase thrombolysis: results of a randomised double blind European Cooperative Study Group trial. Br Heart J 1992;67:122-8.

17. Mueller HS, Forman SA, Menegus MA, Cohen LS, Knatterud GL, Braunwal
E. Prognostic significance of nonfatal reinfarction during 3-year follow-up: results of the Thrombolysis in Myocardial Infarction (TIMI) phase II clinical trial. J Am Coll Cardiol 1995;26:900-7.

18. Ohman EM, Califf RM, Topol EJ, et al. Consequences of reocclusion after successful reperfusion therapy in acute myocardial infarction. Circulation 1990;82: 781-91.

19. Gibson CM, Karha J, Murphy SA, et al. Early and long-term clinical outcomes associated with reinfarction following fibrinolytic administration in the Thrombolysis in Myocardial Infarction trials. J Am Coll Cardiol 2003;42:7-16.

20. Gash AK, Spann JF, Sherry S, et al. Factors influencing reocclusion after coronary thrombolysis for acute myocardial infarction. Am J Cardiol 1986;57:175-7.

21. Gulba DC, Barthels M, WesthoffBleck $M$, et al. Increased thrombin levels during thrombolytic therapy in acute myocardial infarction: relevance for the success of therapy. Circulation 1991;83: 937-44.

22. Harrison DG, Ferguson DW, Collins $\mathrm{SM}$, et al. Rethrombosis after reperfusion with streptokinase: importance of geometry of residual lesions. Circulation 1984 69:991-9.

23. Weitz JI. Low-molecular-weight heparins. N Engl J Med 1997;337:688-98. [Erratum, N Engl J Med 1997;337:1567.]

24. Thompson PL, Aylward PE, Federman $\mathrm{J}$, et al. A randomized comparison of intravenous heparin with oral aspirin and dipyridamole 24 hours after recombinant tissue-type plasminogen activator for acute myocardial infarction. Circulation 1991; 83:1534-42.

Copyright (c) 2006 Massachusetts Medical Society. 